\title{
Research on the Application of Computer Network in Minority Preparatory English Teaching Hongxia Dai ${ }^{1, a}$ \\ ${ }^{1}$ Nanchang Institute of Science \& Technology, Nanchang, Jiangxi, 332000 \\ aemail,
}

Keywords: Computer Network, Minority, Preparatory English Teaching

\begin{abstract}
Minority Preparatory education is an important part of minority higher education. It transports high-level talents for ethnic minority areas and promote the development of ethnic minority areas. In the minority preparatory education, because there is a big difference in student life and cultural environment, there are levels of students on the basis of knowledge and access to education is quite different, which makes the unified educational model for teaching, can not achieve the desired teaching effect. Thus, the National Minority Preparatory English teaching needs to constantly explore new teaching methods. In this paper, a computer network in Minority Preparatory English Teaching has been explored a new teaching model and finally improve teaching effectiveness.
\end{abstract}

\section{Introduction}

Minority Preparatory education means: College recruit minority high school graduates in remote areas, the basics of education through a school year, and then the students sent to universities professional learning. In minority students, since students home remoteness, English level is generally low, therefore, minority preparatory education, the need to pay particular attention to English education. However, to enhance students English level is concerned, there is a big challenge. With the development of computer networks, computer network technology has become an important teaching college English teaching methods, how to apply computer network technology to English teaching in minority Foundation, which has become an important issue Preparatory English teaching, following this be explored.

\section{Minority Preparatory English Teaching Widespread Problem}

Teaching Materials are Narrower and Students have Less Exposure to English. Colleges Foundation English teaching materials used for minority students more difficult, the selection range of materials substantially covering the United States, Britain classic article, because the content of these teaching vocabulary large, students would be more difficult. In the preparation of the Preparatory English teaching materials, teaching materials using objects is set to master the 1200 words of English students, but most minority students are lower than the corresponding requirements, which will make the teaching of English teaching can not achieve the desired effect [1]. And, in addition to teaching materials, as well as supporting workbooks, but their English poor foundation, students are basically not actively supporting the use of English Workbook. In addition, since basically only minority students in English class to exposure to English, had little contact with English in class, and the students' exposure to English single channel, less exposure to English, students can only learn English through English classroom.

English Learning English Polarization Occurs and Student's Motivation is not Strong. With Minority Preparatory College Students of the rising number of such gaps in students' English proficiency is increasing, but because teachers colleges and universities is not strong, the majority of colleges and universities are taking a unified model of large classes, are unified use of textbook. English Education in Minority Preparatory beginning stage, the achievement gap between students of English is not obvious, but with the increasing difficulty of the course, students learn basic English to English influence more and more obvious, and slowly began to appear student 
achievement polarization phenomena [2]. Because of the level of English among students is a big gap, teacher uniform teaching methods and content, a higher level of English students will not be a greater increase, while allowing a lower level of English students can not understand so that students can not actively participate in the teaching of English, so that students lose interest in the teaching of English, the loss of English learning initiative. Students in the same class the emergence of the phenomenon of polarization, which in turn would affect the effectiveness of teaching English class, increase the difficulty of teaching work [3].

The Teaching Methods Behind. English teaching is basically indoctrination-based, mainly in the classroom the teacher is talking, listen to the following students and English proficiency can not effectively exercise. In the Preparatory English teaching, the traditional mode of education has the characteristics of a closed classroom with a teacher as the main teaching center, students can not choose their own learning content required for students between the content can not be learned in the classroom interaction, only students and teachers, textbook one-way interaction, learning English is suppressed initiative and enthusiasm, thus limiting the development of students' English proficiency. Further, the content of textbooks can not meet the English proficiency of students in many aspects, the traditional cramming education can not make the needs of students learning English to be met, although many university teachers can see these problems, but no ability to change.

\section{Computer Network in Minority Preparatory English Teaching}

In recent years, ethnic preparatory education is basically installed in the computer and Internet coverage of classroom conduct. English teaching content-based teaching materials to teachers and collect information over a computer network to make video courseware. Before you start teaching English students can understand the content of the course through a computer network, and based on their interest, understanding and course-related information to help students better understand the course content, to keep pace Course. Teachers can release some tasks require students through the computer network to find relevant information, access to relevant information in order to complete the task of teachers released [4]. The specific teaching tasks: Looking for course-related information through the computer network, to advance understanding of the course contents and the relevant vocabulary, understand the origins of the textbook authors in the background, or learn textbooks festival; students complete the course independently via a computer network involved in word meaning, pronunciation learning. With the application of computer network in Minority Preparatory English teaching, enables students and students in the classroom interaction between students and teachers, teachers to achieve synchronous tutoring for students teaching content.

\section{The Role of The Computer Network In Minority Preparatory English Teaching}

Provide Students with More Opportunities for English. Computer Network in Minority Preparatory English teaching has effective solution to the traditional way of teaching English matriculation single issue, to provide students with more opportunities for exposure to English. There are plenty of English learning resources in a computer network, and in which there are many English teaching platform can help students improve their English skills in all aspects, so as to solve the problem of a single textbook, and meet the needs of students with different learning English [5]. Through the computer network, students have access to native English, while to communicate with other people in the process of learning English, so that students have more opportunities for exposure to English.

Enhance Student English Learning Self-Confidence and Improve Students' Motivation to Learn. Computer Network in Minority Preparatory English teaching can inspire students to learn English initiative, enhance their self-confidence. Minority Students learn course content through a computer network and based on their interest, understanding and course-related information that can help students better understand the teaching contents, in the classroom can keep up with the pace of teaching, the teacher's questions students can easily answer, the content of textbooks, 
students can understand, which would allow students to self-confidence is enhanced. In addition, students learn the content of classroom teaching through a computer network, and extend to other content, can stimulate students 'interest in learning English, to improve students' English learning initiative. Students are no longer a single listen to the teacher to explain, but to understand the course contents from a computer network and in the classroom with the teacher teaching interaction, which avoids the disadvantages of teacher unilateral impart knowledge to some extent, so that students can participate to classroom teaching to achieve teaching student-centered goals.

Promote Update Teaching Methods To Improve Teaching Efficiency. Computer network application to teaching, teachers can take to promote the teaching of updating. In traditional preparatory English teaching, teachers need to spend a lot of time writing on the blackboard, and the need to wait for students to take notes in order to learn the next lesson content, in the teaching process, teachers back to back language statements, teaching content, you need to occupy most of your time in class, and teaching effectiveness is not ideal. Through the computer network, teachers can design their own educational courseware content into the required curriculum and background information embedded in the courseware to meet the different needs of students basic English, and significantly shorten the time writing on the blackboard, and language courses in a statement, adding courses content of teaching, improve classroom efficiency [6]. In addition, teachers can update teaching methods through a computer network, such as network teaching, teaching through online, you can create a relaxed teaching environment, and promote communication between students and teachers, to ease pressure on students in the classroom enable the students to straighten out the ideas in the teaching process, to promote students' independent thinking.

\section{Conclusion}

Computer networks to Minority Preparatory English teaching can solve the traditional way of teaching English matriculation single issue, to provide students with more opportunities for English, the students according to their own interests, the use of computer networks for English learning, understanding and courses related information, can help students to better understand the teaching contents, in the classroom teaching can keep pace, to a certain extent, enhance the students' English learning self-confidence, improve students learning English initiative. In addition, through the computer network in Minority Preparatory English teaching, student life can be solved due to differences in cultural environment, as well as students with basic knowledge of the existence of a problem to obtain different levels of education, resulting in a unified mode of teaching can not achieve the expected teaching effect to enhance students' self-learning ability, but also expanded the students' thinking and accelerate the accumulation of the students' own knowledge for the training of minority talent and the development of ethnic minority areas play an important role.

\section{References}

[1] Liu Junhui. Cooperation Inquiry Teaching in Oral English Teaching - A Case Study of Logistics Spoken English Teaching [J]. Ningbo University of Technology, 2011,04: 101-105.

[2] Gong Liang. Network Environment Junior English Teaching-Case of Shanxi "Music Academy" in English Teaching Application Platform [J]. Based on Yanbian Education College, 2015,01: 91-93.

[3] Liu Yan. Mu-class application and influence in College English Teaching - Comment on "Approaches to English Teaching Reform Exploration" [J]. Contemporary Education Science, 2015, 15: 7-36.

[4] Wang Fang. Application Research "flipped classroom" in College English Teaching - A Case Study of Teaching English News Network [J]. Education Forum, 2016, 16: 246-248.

[5] Bao Jiayin. Huang Hua. Micro-lesson English Teaching in Higher Professional Application method - Zhejiang International Maritime College of Maritime English example [J]. Vocational Education, 2016, 03: 56-57. 
[6] Zhang Xiangqing. TBLT under Multimedia Network Environment in English Teaching [J]. Education (Higher Educational Research and Evaluation), 2014, 05: 23-24. 